\title{
Egg Production of Paramphistomata in Dairy Cattle
}

\section{J. Liao ${ }^{1 *}$, H. D. Wang ${ }^{2}$, J. Q Ye ${ }^{1}$, X. D. Jiang ${ }^{3}$, W. Zeng ${ }^{4}$, J. Zh. Ling ${ }^{5}$, Y. Fu ${ }^{5}$ and Y. J. Wei ${ }^{1}$}

${ }^{1}$ Sichuan Academy of Animal Sciences, Chengdu, 610066, Sichuan, P.R. China

${ }^{2}$ Lanzhou Institute of Animal and Veterinary Phamarceutics Sciences, Chinese Academy of Agriculcural Science, P.R. China

${ }^{3}$ Deli Dairy Cattle Farm of Hongya, Sichuan, P.R. China

${ }^{4}$ Yangping Breed Dairy Cattle of Hongya, Sichuan, P.R. China

${ }^{5}$ Gongfa Breed Dairy Cattle of Hongya, Sichuan, P.R. China

\begin{abstract}
This paper deals with egg output of Paramphistomata in dairy cattle. Six dairy cattle, four Chinese Holstein and two Simental cows whose ages were 4.1, 6.4, 6.8, 7.3, 7.8, 9.1 years, were examined. Total egg amounts of Paramphistomata were calculated in total fecal quantity of a cow per day. The results were $1.8 \times 10^{6}, 4.1 \times 10^{6}, 1.8 \times 10^{7}$, $9.0 \times 10^{6}, 1.5 \times 10^{7}$ and $4.3 \times 10^{5}$ eggs. Dissection was used to collect paramphistomata samples from rumen, omasum, rectum and cecum of the six dairy cows completely. The results were that total worm numbers were $1660,1180,5047$, 3115,4463 and 132 showed that egg output of paramphistomatata were 1084, 3458, 3524, 2907, 3360 and 3258 per worm per day, respectively. The average egg output was 2932 eggs/worm/day. On the other hand, the slide samples of 371 paramphistomatata worms from the six autopsied cows were identified for species. The results from these morphological analyses were that there were ten species assignable to four genus, Paramphistomum (P. cervi, $P$. goto and P. gracile), Calicophoron (C. skrjabini and C. calicophorum), Ceylonocotyle (C. Iongicoelium, C. streptocoelium, C. dicranocoelium and C. scoliocoelium) and Homalogaster (H. paloniae), 2 families, Paramphistomatidae and Gastrodiscidae.
\end{abstract}

Keywords: Paramphistomatata; Egg output; Dairy cattle

\section{Introduction}

Paramphistomiasis is one of the most common parasitic diseases of ruminants, including cattle, buffalo, yak, goat, sheep deer etc. [1]. While some studies suggest that paramphistomiasis may be a relatively unimportant parasite for dairy cattle [2,3], but it may become a more serious disease in other settings [4]. For example, the infective rate of paramphistomata disease was $84.24 \%$ in dairy cattle in Hongya, Sichuan, China [5]. The host may die as a result of the motility of the paramphistomata larva which can lead to damage to the host's liver or other organs. Unfortunately, it is difficult to cure infected dairy cattle because of medicinal issues, such as the curative level, side-effects etc. [6].

Livestock and poultry parasitic diseases are usually diagnosed using egg counts and worm numbers in infected animals. The latter is rarely used because of the requirement to slaughter the animal, with an obvious cost impact. Therefore, the egg count technique becomes the common method in monitoring and control of parasitic disease [7]. For example, Fanyao et al. [8] thought when the EPG (numbers of eggs in one gram feces) value of nemotode's or hepatica's eggs exceeds 1000 or 300 respectively, then infected goats or sheep should be treated, respectively. Further, the egg output for many parasites, such as Schistosoma japonicum, Fashiola hepatica, Hamonchus, Oesophagostomum, Chabertia, Gaigeria, Bunostomum, Trichostrongylus, Ostertagia, Cooperia and Nematodirus [9,10], etc., are studied for not only diagnosis, but also other biological characteristics. Highly relevant here is that the egg output of paramphistomata worms has not been reported.

\section{Materials and Methods}

\section{Dairy cattle}

Six dairy cows, four Chinese Holstein and two Simental cows were confirmed to be infected with paramphistomiasis using the method of examining eggs in the feces. Their ages were 4.1, 6.4, 6.8, 7.3, 7.8, 9.1 years, respectively. For collection of their feces, animals were normally fed all alone during the test period.

\section{Paramphistomata species in dairy cattle}

The paramphistomata samples were collected from autopsied cows. Samples were randomly selected to be mounted as slide samples using established methods $[8,10]$. Morphological analysis was performed to identify paramphistomata species by reference to standard texts [1012].

\section{Egg count of paramphistomata}

Before dairy cattle were slaughtered, its feces was fully collected and mixed to obtain the EPG value of paramphistomatata eggs using the method described by $[13,14]$ and total egg amount in fecal sample of a dairy cattle per day by the following formula. It was repeated in 3 successive days:

\section{Total eggs $=\mathrm{EPG} \times$ Feces quantity $(\mathrm{g}) / \mathrm{d}$}

Autopsy was used to collect essentially complete paramphistomata worm samples from the rumen, omasum, rectum and cecum of the dairy cattle completely and the worms were counted. Analysis was repeated on three successive days.

Egg output was calculated a paramphistomata worm per day by the following formula;

$$
\text { Eggoutput }=\frac{\text { Total eggs }}{\text { Total Paramphistomata }}
$$

*Corresponding author: Dr. D. J. Liao, Sichuan Academy of Animal Sciences, Chengdu, 610066, Sichuan, P.R. China, E-mail: liaodjin@yahoo.com.cn

Received March 30, 2012; Accepted April 20, 2012; Published April 26, 2012

Citation: Liao DJ, Wang HD, Ye JQ, Jiang XD, Zeng W, et al. (2012) Egg Production of Paramphistomata in Dairy Cattle. J Bacteriol Parasitol 3:136. doi:10.4172/21559597.1000136

Copyright: $\odot 2012$ Liao DJ, et al. This is an open-access article distributed unde the terms of the Creative Commons Attribution License, which permits unrestricted use, distribution, and reproduction in any medium, provided the original author and source are credited. 


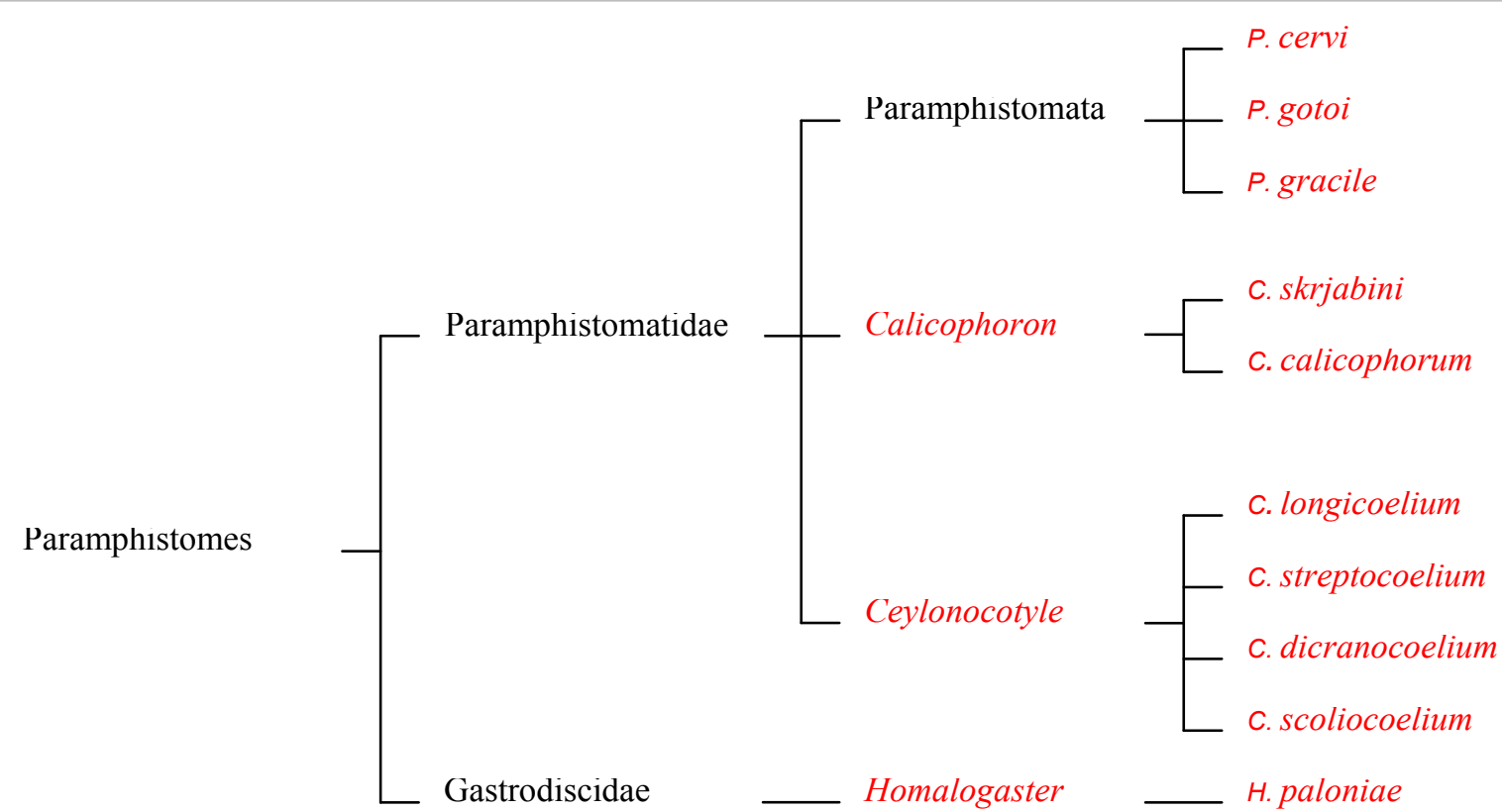

Figure 1: Systematic tree of paramphistomata's species of dairy cattle in Hongya

\begin{tabular}{|c|c|c|c|c|c|c|}
\hline No. & Breed & $\operatorname{EPG}(\bar{x})$ & Quantity of feces $(g) / d$ & Total eggs/d & Worms & Eggs/Worm/d \\
\hline 1 & Holstein & 194 & 9300 & $1.8 \times 10^{6}$ & 1660 & 1084 \\
\hline 2 & Holstein & 100 & 40800 & $4.1 \times 10^{6}$ & 1180 & 3458 \\
\hline 3 & Holstein & 760 & 23400 & $1.8 \times 10^{7}$ & 5047 & 3524 \\
\hline 4 & Holstein & 295 & 30700 & $9.0 \times 10^{6}$ & 3115 & 2907 \\
\hline 5 & Simental & 855 & 17500 & $1.5 \times 10^{7}$ & 4463 & 3360 \\
\hline 6 & Simental & 50 & 8600 & $4.3 \times 10^{5}$ & 132 & 3258 \\
\hline
\end{tabular}

Table 1: Egg output of paramphistomata in dairy cattle.

\section{Results}

\section{Paramphistomata species}

371 slide samples of the paramphistomatata samples from the autopsied cows were classified in our laboratory. The results from morphological analysis were that there were ten species relegating to four genus, Paramphistomum (P. cervi, P. gotoi and P. gracile), Calicophoron (C. skrjabini and C. calicophorum), Ceylonocotyle (C. longicoelium, C. streptocoelium, C. dicranocoelium and C. scoliocoelium) and Homalogaster (H. paloniae), two families, Paramphistomatidae and Gastrodiscidae (Figure 1).

\section{Egg output of Paramphistomata}

$1660,1180,5047,3115,4463$ and 132 paramphistomata worms were collected from the dairy cattle, respectively. Total egg numbers were $1.8 \times 10^{6}, 4.1 \times 10^{6}, 1.8 \times 10^{7}, 9.0 \times 10^{6}, 1.5 \times 10^{7}$ and $4.3 \times 10^{5}$ in their feces per day. The results showed that the egg output of paramphistomata in these dairy cattle were 1084, 3458, 3524, 2907, 3360 and 3258 per worm per day, respectively. Subsequently, average of egg output was 2932 eggs/worm/day (Table1).

\section{Discussion}

\section{Species of Paramphistomata in dairy cattle at Hongya}

We investigated the species of paramphistomatata of cattle and buffalo at Hongya in 1983. The results were that there were seven species,
Fischoederius explanatus, Carmyerius synethes, Ceylonocotylev cheni, C. sinuocoelium, Paramphistomum gotoi and Cotylophoron cotylophorum, relegating to five genus(Fischoederius, Carmyerius, Ceylonocotylev, Paramphistomum and Cotylophoron), two families (Paramphistomatidae and Gastrothylacidae) $[15,16]$. Interestingly, gastrodisciasis is a normal consequence of paramphistomiasis in cattle and buffalo in this region, but this did not appear in the cattle included in this investigation. It, therefore, remains unclear whether gastrodisciasis can not invade into dairy cattle or that the incidence has subsided for reasons unknown.

\section{Egg output of Paramphistomata in dairy cattle}

Among six anatomized dairy cattle, egg outputs of paramphistomata in dairy cattle were estimated to be 1084, 3458, 3524, 2907, 3360 and 3258 eggs/worm/day. This demonstrates that there was a great difference in the level of egg production, between 2907-3524 and 1084. The dairy cattle examined did not exhibit any clinical signs of illness prior to slaughter. Hence, the large difference in egg output might be not due to disease in the cow with 1084 eggs influencing the paramphistomata worms laying eggs. Other parasites, such as Ascaris suum, exhibit a ten-fold variance in egg production [10]. Therefore, the near three fold variance in egg output of paramphistomata may be a natural characteristic.

\section{References}

1. Jiang XL, Zhou WL, Liao DJ (2004) A survey of animal and poultry parasites 
Citation: Liao DJ, Wang HD, Ye JQ, Jiang XD, Zeng W, et al. (2012) Egg Production of Paramphistomata in Dairy Cattle. J Bacteriol Parasitol 3:136. doi:10.4172/2155-9597.1000136

Page 3 of 3

in Sichuan Province. Sichuan Publishing House of Science \& Technology, Chengdu.

2. Wang WJ, Ying HCh, Wang LY (2003) Prevention and cure of normal parasitosis of dairy cattle in Daqing. Heilongjiang J Anim Vet 30-31.

3. Yan ChP, Wang ChR, Xue KY (2003) Controlling technique of main parasitosis of dairy cattle in Haerbin. Chin J Vet Parasitol 11: 49-52.

4. Cao ShG, Li ZhZh, Zhao HW, Mu RH, He XSh (2005) Investigation and cure of dairy cattle's parasitosis in Lijiang. Chin J Vet Parasitol 13: 55-56.

5. Liao DJ, Zhen Zh, Jiang XJ, Ling JZh, Wang HD (2005) Investigation and treatment of paramphistome disease for dairy cattle in Sichuan Province. Chin $\mathrm{J}$ Dairy Cattle 51-53.

6. Wang HD, Liao DJ (2008) Species investigation of Paramphistomum spp. and analysis of its infection trendo in dairy cattle at Hongya. Chin $\mathrm{J}$ Vet Sci 28: 90-93.

7. Liao DJ (2005) A diagnostic technique of domestic animals Parasitology. Chin J Vet Parasitol 13: 8-9.

8. Kong FY, Lan QF, Zhao ShY, Liu WD, Zhan YT, et al. (1981) Animal parasitology. Agricultural Publishing House of China, Beijing, China.
9. Reinche RK (1983) Veterinary Helminthology. Butterworth Publishers Pvt. Ltd., China.

10. Zhao HY, Liu JH, Wang ZhK, Chen ShY, Jin JSh, et al. (1996) Prevention and cure of animal and poultry parasitology. Sci \& Tech Publishing House of Jilin, Changchun, China.

11. Скрябин К.И (1949) Трематоды жнвотных и человека Т.ІІІ.Изл. АН СССР Москва, Russia

12. Chen XT, Cai ShD, Li GY, Tang ZhZh, Tang CT, et al. (1985) Fauna Sinica (Digenea, Trematoda, Platyhelminthes). Sci Tech Pub House, Beijing, China.

13. Liao DJ (1996) Study on the new egg count technique for $M$. hirudinaceus and A. suum. Vet Parasitol 61: 113-117.

14. Liao DJ (2000) New diagnosing technique of fascioliosis in sheep and cattle. Chin J Vet Parasitol 8: 18-22.

15. Jiang XL (1987) Investigation of cattle's parasite system in Sichuan. Sichuan J Anim Vet 16-18.

16. Shen J, Huang B, Liao DJ, Li GQ (2004) A list of parasites for livestock and poultry in China. Chinese Publish House of Agricultural Science and Technology, Beijing, China. 